\title{
ODOARDO BECCARI AND ENRICO D'ALBERTIS IN AUSTRALIA AND NEW ZEALAND, 1878: BOTANICAL AND ZOOLOGICAL COLLECTIONS
}

\author{
by John Leslie Dowe
}

(with two text-figures, three plates, one table and two appendices)

\begin{abstract}
Dowe, John L. 2016: (15:xii). Odoardo Beccari and Enrico D’Albertis in Australia and New Zealand, 1878: botanical and zoological collections. Papers and Proceedings of the Royal Society of Tasmania 150(2):27-41. https://doi.org/10.26749/rstpp.150.2.27 ISSN 0080-4703. Australian Tropical Herbarium, James Cook University, Smithfield, Queensland 4878, Australia. Email: john.dowe@my.jcu.edu.au

Though acclaimed for his scientific exploration and botanising in Borneo, New Guinea and Sumatra, Odoardo Beccari travelled briefly through Australia and New Zealand between 19 January and 5 April 1878. During this time, Beccari was in the company of navigator and ethnologist Captain Enrico Alberto D’Albertis. Although primarily a leisure tour, Beccari and D’Albertis engaged in botanical and zoological collecting when circumstances allowed. Specimens were collected in Queensland at Percy Islands and the Brisbane Botanic Garden; in New South Wales at the Blue Mountains; in Tasmania at Launceston, Corra Linn, Mount Wellington and Huon Road and in New Zealand at Bluff, Napier, Moeraki and Titirangi. Of the Australian and New Zealand specimens that have been located, the main life-form is bryophytes, with about 46 taxa of which 11 were described as new based on their collections. Only 13 herbarium specimens of vascular plants have been located and two of these were described as new taxa and represent type specimens. Of the zoological collections, about 20 ant (Formicidae) specimens were collected of which three were described as new taxa. Also collected were two specimens of earthworms (Lumbricidae), both of which were described as new, and three crustaceans (Amphipoda), two of which were described as new. This paper outlines their travel itinerary, provides a critical assessment of the collections, and examines the collaboration between Beccari and Baron Ferdinand von Mueller, Victorian Government Botanist at the time.
\end{abstract}

Key Words: Arecaceae, Australia, botanical and zoological collections, bryophytes, Captain Enrico D'Albertis, Ferdinand von Mueller, Formicidae, New Zealand, Odoardo Beccari, Tasmania.

\section{INTRODUCTION}

The visit of Odoardo Beccari and Captain Enrico D'Albertis to Australia and New Zealand in 1878 is a somewhat forgotten episode in the history of botany and zoology of these countries. Born on 16 November 1843 in Florence, Italy (died 25 October 1920, Florence), Beccari (pl. 1) was one of the most productive and influential botanists/naturalists of his era to work and collect in the biogeographical region of Malesia, an area extending from Sumatra in the west to the Philippines in the north and east to New Guinea (Beccari 1924, van Steenis-Kruseman 1950, Pichi-Sermolli \& van Steenis 1983, Chazdon \& Cranbrook 2002). Between 1865 and 1878, Beccari made large collections of botanical, entomological, ethnographic, ornithological and zoological specimens which he remitted to scientific institutions in Italy, mainly the Museo di Storia Naturale dell'Università di Firenze (van Steenis 1952, Clauser et al. 2013, Andreone et al. 2014) and the Museo Civico di Storia Naturale di Genova (Doria 2010, Clouse \& Giribet 2012). Beccari's Malesian collections were studied by various specialists, and many thousands of new taxa were based on his specimens. The botanical collections were primarily worked on by Beccari himself at the Università di Firenze, where he maintained the herbarium (Cuccuini 2009), and the results were written up in journals that he established, such as the Nuovo Giornale Botanico Italiano, 1869-1871, and Malesia, 1877-1883 (Nepi 2009). Other significant monographs and papers, particularly on palms, were later published in journals such as Webbia, Annales $d u$ Jardin Botanique de Buitenzorg, Annals of the Royal Botanic
Garden, Calcutta and The Philippine Journal of Science among others. From about 1880, he directed his attention almost solely to the study of palms (Arecaceae), and established the world's largest and most important palm herbarium at Florence (Cuccuini \& Nepi 2006). Many biographical sketches have been prepared on Beccari (Burkill \& Moulton 1921, Jackson 1922, Pollacci 1935, Biagioli 2005, George 2009), and portray him as a brilliant, productive, singleminded "complete" scientist but a somewhat impulsive, impatient and misanthropic individual particularly in later life (Moore 1981, Cuccuini \& Nepi 2006).

Beccari's travelling companion during the Australian and New Zealand journey was Captain Enrico Alberto D'Albertis (born 23 March 1846, Voltri, Italy; died 3 March 1932, Genoa, Italy) (pl. 2), retired Italian Navy Officer, navigator, writer, philologist, ethnologist and philanthropist (Orlandi 2009). Captain D'Albertis was the cousin of Count Luigi Maria D'Albertis, the renowned explorer, ethnologist, and botanical and zoological collector (D'Albertis 1880, Gnecchi-Ruscone 2011). As a result of his travels throughout the world, Captain D'Albertis established a significant collection of ethnographic and maritime artefacts (Fornaroli 1935), as well as marine animal, algae and plant specimens (Nizamuddin et al. 1978, Capocaccia \& Poggi 1982). His navigational pursuits took him around the world three times (including a second visit to New Zealand in 1896 and to Australia in 1910), a circumnavigation of Africa and a reenactment of the voyage of Christopher Columbus to San Salvador Island using instruments modelled on those of the original voyage (Fornaroli 1935, De Pascale 2008, 2009). 


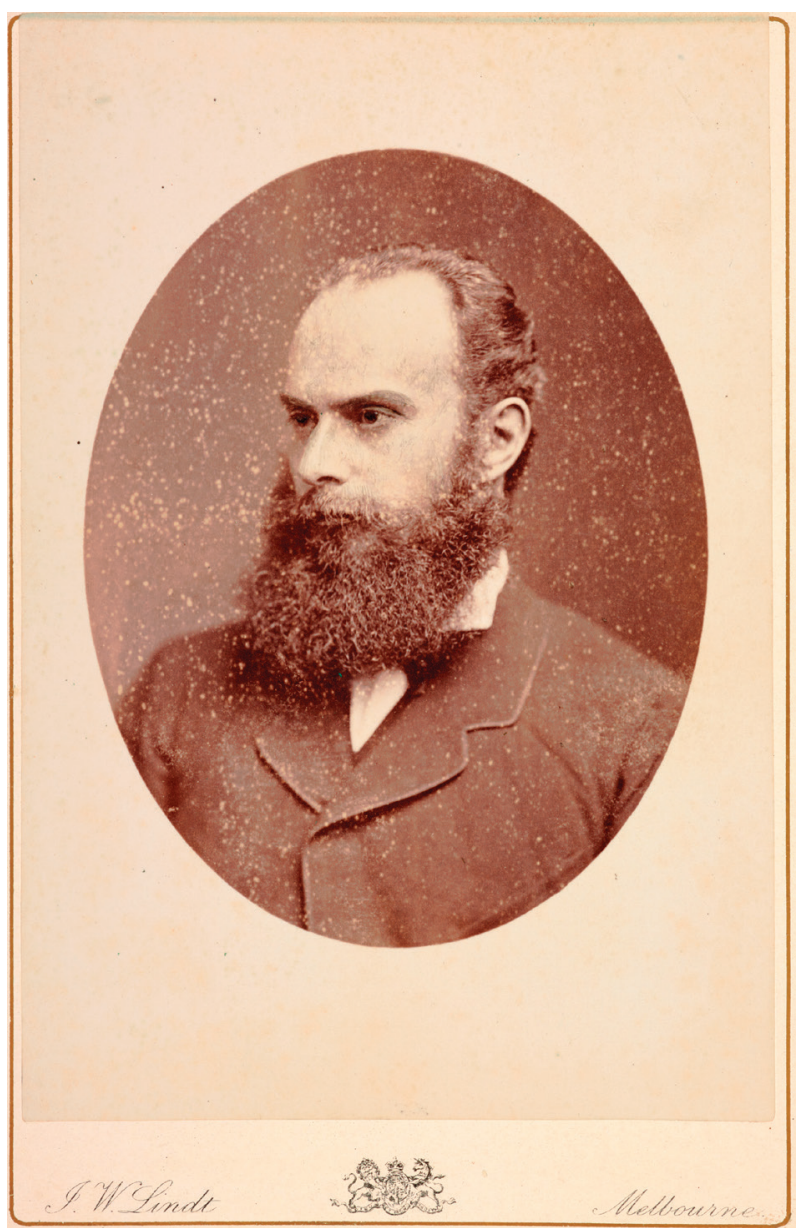

PLATE 1 - Odoardo Beccari, 9 February 1878, carte-de-visite by John William Lindt, Melbourne. Presented to Julius van Haast, 4 March 1878. From the Haast Family collection [PA0132], Alexander Turnbull Library, Wellington, New Zealand.

In 1886, D'Albertis began construction of the spectacular Castello di Montegalletto in Genoa in the Gothic revival style, firstly to be used as his home and, secondly, to store and display his ethnographic and maritime collections. Upon his death in 1932, the castle was donated to the city of Genoa and renamed Castello D'Albertis (Surdich 1985), and since 2004 has been operating as the Museo delle Culture del Mondo (De Palma 2008).

Unlike the extensive documentation of Beccari's Malesian explorations, little has been written about his activities and collecting pursuits in Australia and New Zealand. Despite this, some important collections were made of bryophytes, ants, earthworms, crustaceans and vascular plants, and amounting to about 84 known specimens. Beccari and D'Albertis were also active in visiting botanic gardens and museums in Australia and New Zealand, and engaging and socialising with botanists, naturalists, statesmen and politicians. The collaboration between Beccari and Baron Ferdinand von Mueller, Government Botanist of Victoria, deserves special attention, as they worked together on the New Guinea flora, but met for the first, and only, time during Beccari's visit to Melbourne.

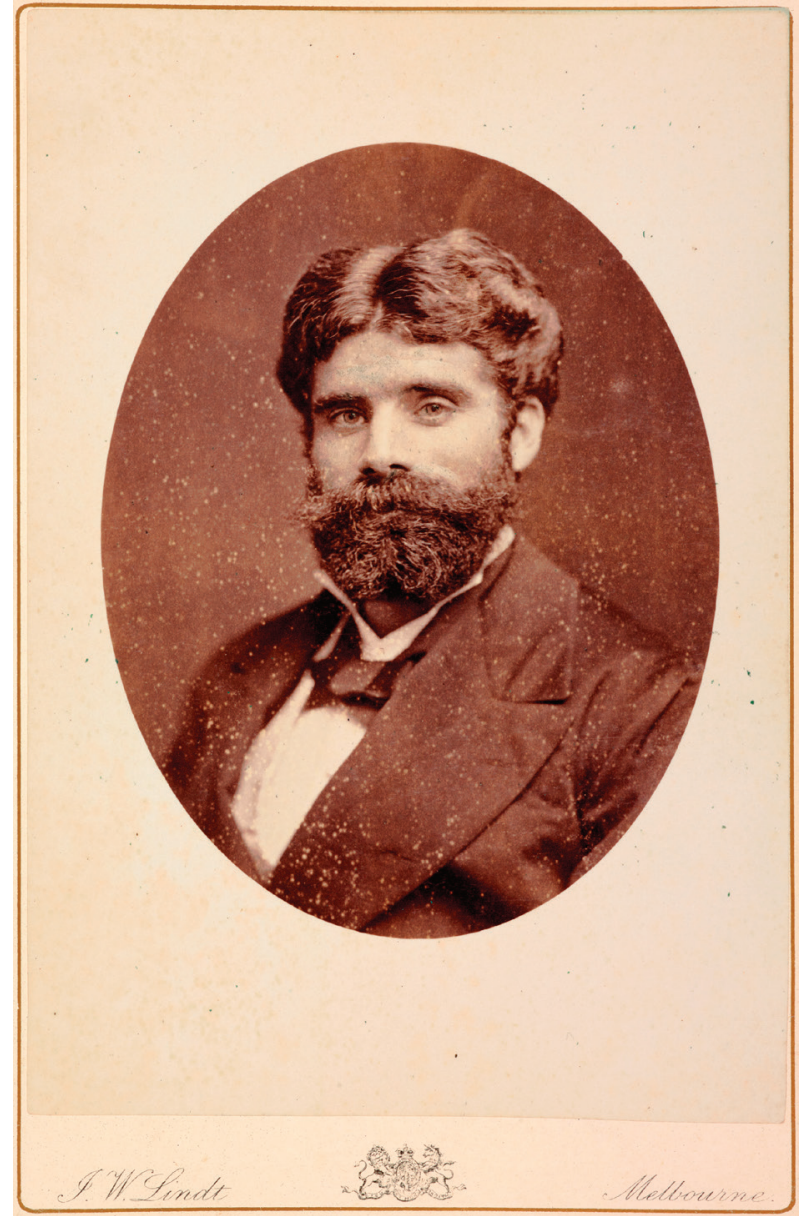

PLATE 2 - Enrico Alberto D'Albertis, 9 February 1878, cartede-visite by John William Lindt, Melbourne. Presented to Julius van Haast, 4 March 1878. From the Haast Family collection [PA-0133], Alexander Turnbull Library, Wellington, New Zealand.

\section{METHODS}

The personal diaries of both Odoardo Beccari and Captain Enrico D'Albertis were made available from library and museum collections in Italy. They were translated either by the author or with assistance from Anna Giulia D'Albertis, great grandniece of Enrico D'Albertis. Quotes from the diaries are included verbatim (in English) and author additions or comments are included in brackets. Correspondence items were accessed through the Mueller Correspondence Project, Royal Botanic Gardens Victoria, the Royal Botanic Gardens Kew archives, the Science Library in the University of Florence and the Alexander Turnbull Library, Wellington, New Zealand. Quotes from letters are included verbatim, and author additions and comments are included in brackets. The specimens they collected were located through herbarium and museum databases, as well as the scientific literature associated with the results of research carried out on their collections, mostly accessed through the Biodiversity Heritage Library online facility. Taxonomy and nomenclature of Australian plants follows the Australian Plant Name Index (www.anbg. gov.au) and for New Zealand plants the Flora of New Zealand (floraseries.landcareresearch.co.nz); bryophyte taxonomy 
follows AusMoss (data.rbg.vic.gov.au); ant taxonomy follows the Atlas of Living Australia (bie.ala.org.au) and AntWeb (www. antweb.org); and earthworms follow ITIS Report (www.itis. gov). It was beyond the scope of this paper to comment on the taxonomic and nomenclatural validity of the species and the names that are herein annotated, but rather they are presented as a record of the collections that Beccari and D'Albertis made during their travels in Australia and New Zealand.

\section{EXPLORATION}

The Australian and New Zealand journey was part of the third extended excursion to be undertaken by Beccari to the "East". Previously, he had carried out two major collecting expeditions in Malesia (Ballard 2009). The first, from April 1865 until March 1868, was in Borneo in what is now Brunei and Sarawak. The second, from January1871 to June 1876, proceeded through the Sunda Islands, and western New Guinea, the present-day Indonesian provinces of Papua and West Papua (Lydon 2014). The third expedition, the one which is in part the subject of this paper, ran from October 1877 to December 1878 . The travel route through Australia (19 January to 23 February and 17 March to 5 April 1878) is shown in figure 1 , and that through New Zealand (26 February to 12 March 1878) in figure 2 . An annotated itinerary for Australia and New Zealand is given in appendix 1.

Although their original intention was to travel around the world together (Anon. 1877), Beccari and D'Albertis parted company about six months into the 12 -month venture. When they returned to Singapore in mid-April 1878, after completing the Australian and New Zealand sections of the voyage, D'Albertis continued on to Hong Kong, China, Japan, the United States, Panama and Peru before returning to Genoa in October 1878 (D'Agnese 2007). Meanwhile, Beccari remained in Indonesia (then Dutch East Indies), at first visiting Java where he stayed at the Buitenzorg Gardens (Kebun Raya Bogor) (1-29 May), before travelling to southern and western Sumatra (30 May-22 October) where he remained for five months making extensive botanical and zoological collections, particularly in the Mount Singalang area (Cora 1880). It is during this time that Beccari made some of his most notable botanical discoveries, including the giant aroid Amorphophallus titanum (Becc.) Becc. ex Arcang. (Titan arum), a species with which Beccari has become singularly associated (Hooker 1891, Gandawijaja et al. 1983). He departed Sumatra on 22 October and arrived back in Florence in December 1878.

Beccari's itineraries, collections and travelling routes in Malesia are well-documented, as he kept thorough notes, detailed specimen information and produced field illustrations and maps (Capocaccia \& Poggi 1982, Graniti 2004). These data were supported by a number of books, including two autobiographical works that dealt with his own explorations (Beccari 1904, 1924), and others written by his early travelling companions, the naturalist Giacomo Doria (Doria 1878) and the explorer/naturalist Count Luigi Maria D'Albertis (D'Albertis 1880). Beccari is renowned for

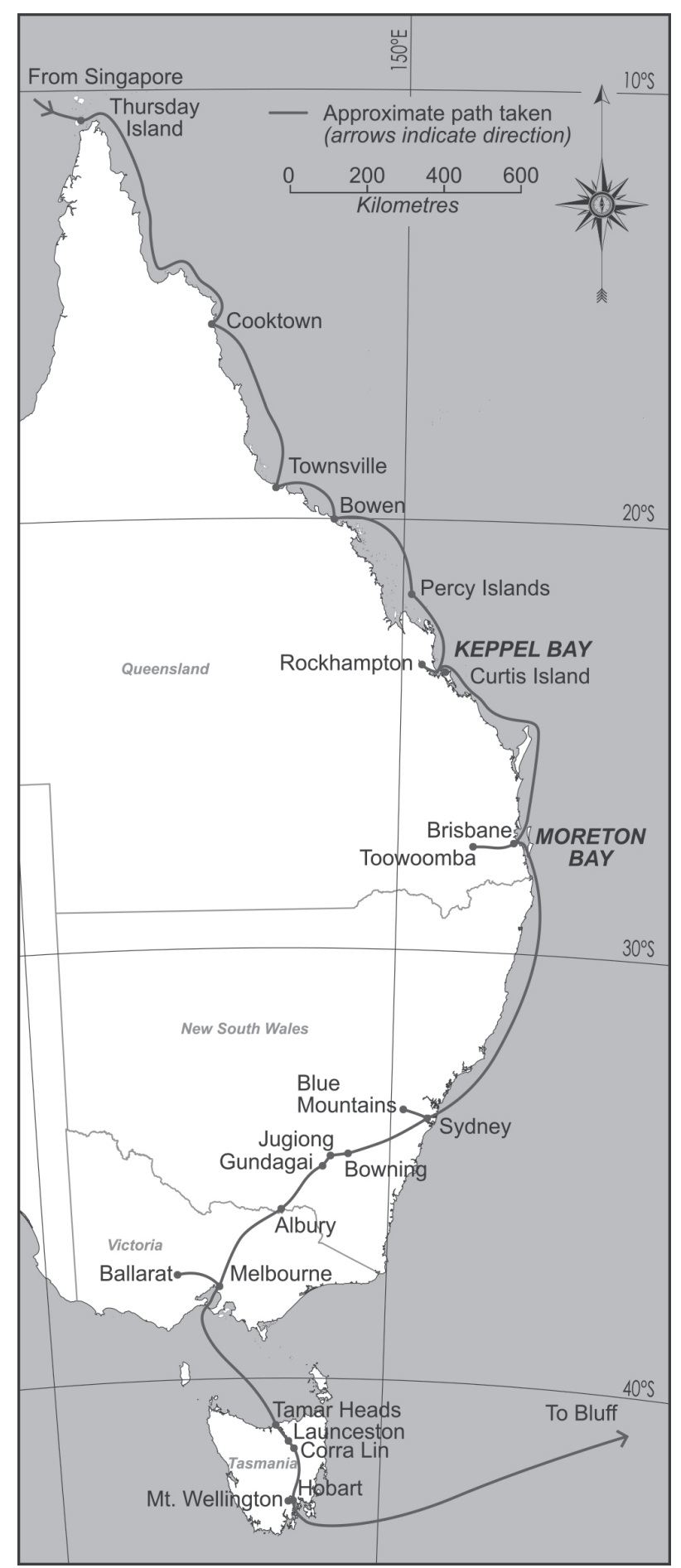

FIG. 1 - Route taken by Odoardo Beccari and Captain Enrico D'Albertis through eastern Australia, 19 January to 5 April 1878. Map prepared by Claire Burton, Cairns Regional Council.

the high quality of his specimens and his enduring taxonomy and nomenclature (Cuccuini \& Nepi 2006). 


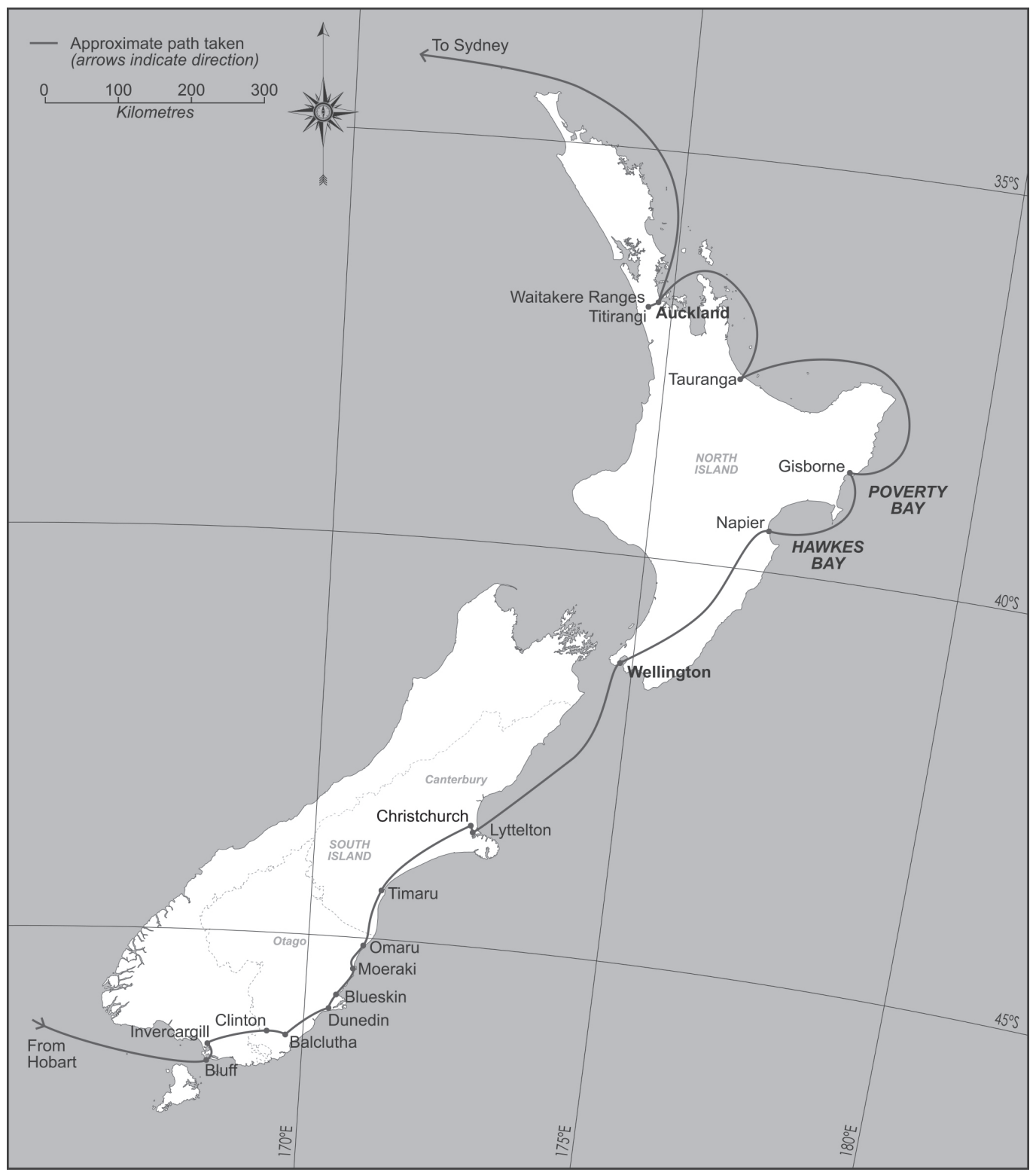

FIG. 2 - Route taken by Odoardo Beccari and Captain Enrico D'Albertis through New Zealand, 26 February to 12 March 1878. Map prepared by Claire Burton, Cairns Regional Council.

\section{SUMMARY OF COLLECTIONS}

Although the visit of Beccari and D'Albertis to Australia and New Zealand in 1878 is unfamiliar to most contemporary botanists and zoologists in these two countries, they made important collections that were mostly returned to institutions in Europe. There the specimens were studied by specialists in various fields and new species were described and published. The specimens collected in Australia and New Zealand included bryophytes (46 specimens) and ants (20), with lesser numbers of vascular plants (13), crustaceans (three) and earthworms (two): a total of 84 specimens (appendix $2)$. The most significant collections were made in Tasmania on Mount Wellington on a single day (19 February 1878) when almost 40 specimens of bryophytes, two new species of crustaceans, and a new species of earthworm, were collected.

The first publication relating to the collections was an annotated list of 39 bryophytes by Hampe \& Geheeb (1881) based on the Beccari collections from Tasmania and New Zealand. This work included four new species. The herbaria to which Beccari sent the bryophytes were not recorded, although it can be suspected that they were first received by the Herbarium Universitatis Florentinae and later distributed from there. Geheeb, one of the authors of that publication, maintained a large personal herbarium in Jena, Germany, which was eventually transferred to the Botanischer Garten und Botanisches Museum Berlin-Dahlem (Sayre 1977). Historical citation data listed some of Beccari's Australian and New Zealand collections as being in the "Herb. Geheeb", so it is assumed that some specimens or duplicates were sent to Geheeb, although no independent documentation of this has been located because of the dismantling and loss of Geheeb's herbarium after his death in 1909 (Sayre 1977). Later, Carl Müller, who also maintained a private herbarium that was similarly donated to the Botanischer Garten und Botanisches Museum Berlin-Dahlem, studied the Beccari collections, and described an additional seven new species (Müller 1897). The bryophyte collection at Berlin was unfortunately devastated during a bombing raid in the Second World War in 1943, thus destroying many type 
specimens and introducing subsequent problems relating to typification and taxonomy (Isoviita \& Ochyra 1990, Ramsay 2006). Some specimens are also cited as being in the "Hb. Levier", the private herbarium of Emilio Levier, a Swiss-born physician and botanist who resided in Florence; his collection is now held in the Herbarium Universitatis Florentinae [FI].

There is evidence that some of Beccari's Australian and New Zealand bryophyte specimens were distributed prior to the 1940 s as they have been located, for example, in the herbaria of the University of Tennessee [TENN], New York Botanical Gardens [NY], Royal Botanic Gardens Sydney [NSW], the Finnish Museum of Natural History, University of Helsinki [H-BR] and the Natural History Museum, London [BM]. As far as it has been possible to investigate, at least 11 new bryophyte taxa were described from specimens collected by Beccari in Australia and New Zealand. This is a relatively high rate considering there were about 46 specimens collected in total, and this is probably not so much a function of the range of specimens collected, but a reflection of the active research on Australian and New Zealand bryophytes at that time and that broad collections were bound to yield novelties. Eponymous taxa, described mostly from bryophyte specimens collected by Beccari and D'Albertis in Australia, are presented in table1.

The ultimate fate of the ant specimens is better known than that of the bryophytes as they were deposited directly into the Museo Civico di Storia Naturale di Genova [MSNG] where they remain today. The collections were studied by Emery $(1886,1887)$ who described three new taxa, one from the Percy Islands and two from the Blue Mountains (appendix 2), of which two, one from each location, represented new subspecies and the other, from the Blue Mountains, a new species. Unlike the bryophytes which were recorded with Beccari as the sole collector, the ants were all recorded with both Beccari and D'Albertis as co-collectors. D'Albertis was later to note that Beccari's main interest during the Australian and New Zealand journey was to make botanical and zoological collections, and that he, Beccari, had shown uncharacteristic patience and restraint when he was required to attend to travel tasks and social events rather than venture into the local areas to collect specimens. Beccari nevertheless recorded D'Albertis as a co-collector for many specimens, for which D'Albertis was apparently grateful (Fornaroli 1935).

Two earthworms, in the genus Megascolides, were collected, one each from Tasmania and New Zealand (appendix 2), and both were described as new species by Cognetti de Martiis (1910). Three crustacean specimens, amphipods in the genus Talitrus, were collected from Mount Wellington, Tasmania, of which two were described as new species by Ruffo (1949). As with the ant specimens, the earthworms and crustaceans were sent to the Museo Civico di Storia Naturale di Genova [MSNG] where many of the specimens are extant. One of the amphipods was later redescribed as a new taxon under a different name by Friend (1987) although the validity of such a proposal is doubtful (appendix 2).

Considering that Beccari's primary research interests involved vascular plant taxonomy, the small number of vascular plant specimens that he collected in Australia and New Zealand is surprising. In total, only 13 herbarium specimens of vascular plants have been located (appendix 2). Seven of these were collected on the Percy Islands, and were the first collections made by the travellers in Australia. Six of these specimens were directly deposited at the time into von Mueller's Phytologic Museum of Melbourne, now the National Herbarium of Victoria, Royal Botanic Gardens Melbourne, and the seventh is at the Herbarium Universitatis Florentinae [FI]. Three vascular plant specimens were collected in Tasmania, of which two represented type specimens (Bitter 1910), and one in New Zealand. Two cultivated specimens of palms were collected from the Brisbane Botanic Gardens (appendix 2), and these are now in the Herbarium Universitatis Florentinae (Cuccuini \& Nepi 2006). The vascular plant specimens were all recorded with Beccari as the sole collector. For some specimens collected on Mount Wellington, purpose-printed labels were prepared with the wording "Piante del viaggio esequito nell'anno 1878

TABLE 1 - Eponymous taxa named for Odoardo Beccari and Enrico D'Albertis, based on species described from specimens they collected in Australia and New Zealand, 1878.

\begin{tabular}{lc}
\hline Taxon & Publication \\
\hline MOSSES & \\
Bryum beccarii Müll.Hal. [Pohlia nutans (Hedw.) Lindb.], Tasmania. Mt Wellington, 19 Feb. & Hedwigia 37: 87 (1898). \\
1878, Beccari s.n. &
\end{tabular}

Leptotheca beccarii Müll.Hal. [Leptotheca gaudichaudii Schwägr.], Tasmania, Mt Wellington, Gen. Musc. Frond. 148 (1901). 19 Feb. 1878, Beccari 22; lectotype: FI; isolectotype: NY00913954.

Mniadelphus beccari Müll.Hal. [Distichophyllum rotundifolium (Hook.f. \& Wilson) Müll.Hal. Rev. Bryol. 8: 27 (1881). \& Broth.]. Tasmania, Mt Wellington, 19 Feb. 1878, Beccari s.n.

Polytrichum beccarii Müll.Hal. [Polytrichum juniperinum Hedw.], Tasmania, Mt Wellington, Hedwigia 36: 345 (1897). 19 Feb, 1878, Beccari s.n.: isotype: H-Br.

\section{EARTHWORM}

Megascolides albertisii (Cognetti de Martiis, 1910) [Aporodrilus albertisii (Cognetti de Martiis, Ann. Mus. Civico Storia Nat. Genova ser. 1910)], Tasmania, Mt Wellington, 19 Feb, 1878, E.D’Albertis \& Beccari s.n.; MSNG. 3, 44: 329 (1910).

The original name appears first, and the current name follows in brackets. Collection date is determined from travel itinerary. Location of specimens is given where known. 


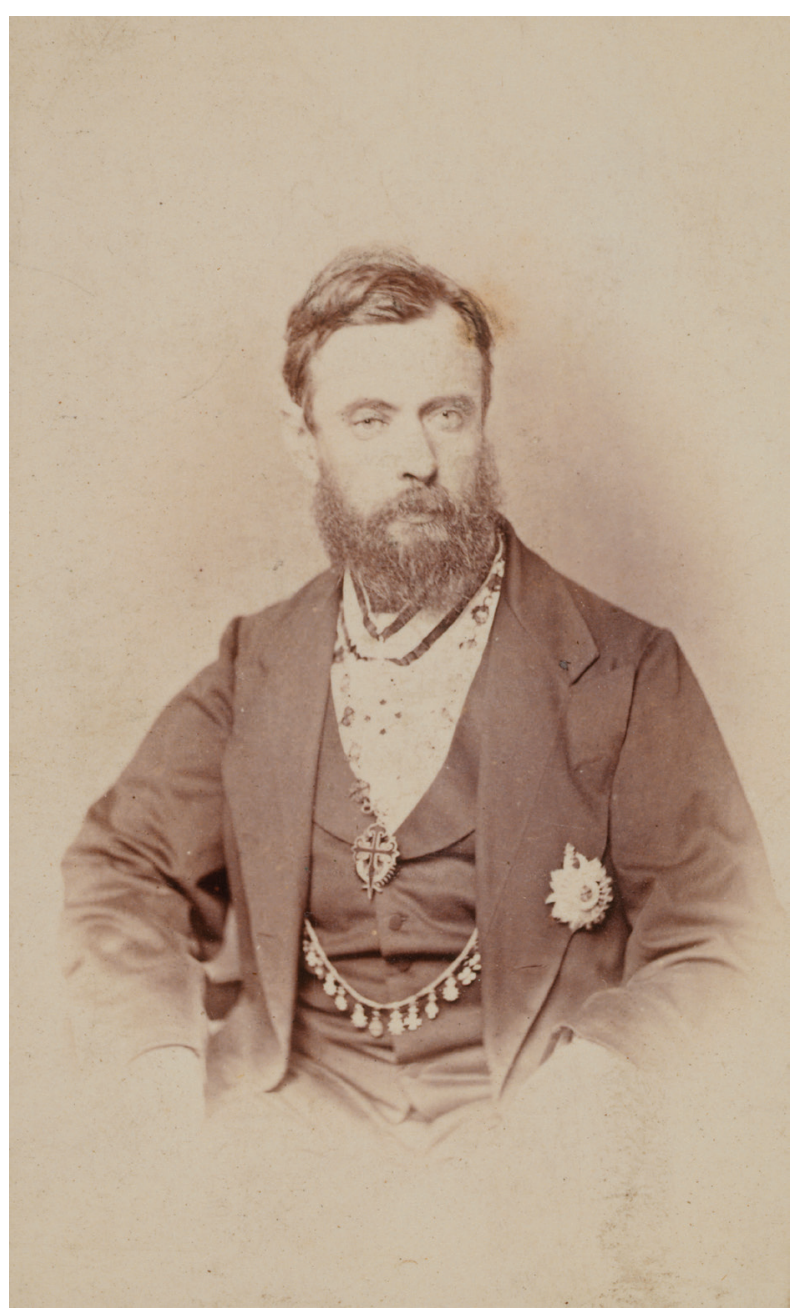

PLATE 3 - Ferdinand von Mueller, circa 1877, carte-de-visite by John Botterill, Melbourne, presented to Captain Enrico D'Albertis during his visit to Melbourne. With permission of the Settore Musei e Biblioteche Comune di Genova.

- Abita:- Sul Monte Wellington Tasmania". It is most likely that other vascular plant specimens were collected, such as from the Blue Mountains in New South Wales, as was noted in D'Albertis' diary, but they have not been located, and further research is required, especially in the Herbarium Universitatis Florentinae where full documentation of the collection has yet to be completed.

Apart from preserved plant specimens, it was noted by D'Albertis that seeds of plants were also collected, but there are no known associated herbarium specimens. For example, in New Zealand, they collected seeds of a number of plants during an overland section of their coach journey between Dunedin and Moeraki, including the New Zealand Cabbage Tree Cordyline australis (Forst.f) Hook.f., 'Ombrellaria' (possibly Schefflera digitata J.R.Forst. \& G.Forst.) and the Nikau palm Rhopalostylis sapida (Sol. ex G.Forst.) H.Wendl. $\&$ Drude (Fornaroli 1935). Beccari was known to have grown plants, in the Orto Botanico di Firenze, that he had collected elsewhere. However, there is no evidence in the plant and seed exchange or cultivated plant lists that any propagation materials or live plants related to those plants collected in Australia or New Zealand were either being cultivated or available for exchange (Mattirollo 1897 , Aiuti 1901).

\section{FERDINAND VON MUELLER AND ODOARDO BECCARI}

In the years prior to Beccari's first personal meeting with Ferdinand von Mueller (pl. 3) in Melbourne, the two had exchanged correspondence and publications, and had collaborated on von Mueller's Descriptive Notes on Papuan Plants (von Mueller 1875-1877). The first few parts of that publication were based on specimens collected by Count L. M. D'Albertis and Andrew Goldie in the southeastern part of New Guinea and sent directly to von Mueller in Melbourne. Subsequent parts were based on Beccari's collections from northwest New Guinea. Those specimens were at first returned to Florence from where duplicates were later sent to von Mueller in Melbourne. The work on Papuan plants was outlined by von Mueller (1877) in a letter to Beccari, in which he stated that:
[31 December 1877] When returning from a phytographic excursion to Shark-Bay and other portions of West-Australia, dear Dr Beccari, I received your kind letter of the 10th September, to which I now briefly reply on board of the Steamer on my route to Melbourne. I received your valuable first part of the publication on Melanesian plants, for which I owe you my best thanks. What a flood of light that work will shed on New Guinea and the neighbouring islands! My "Papuan plants" will be more an account of the $S$. E. vegetation, while your work will more particularly refer to the $N$. W. ...If you desire for comparison any Australian species of Indian genera, I will forward them to you through the Italian Consulate. ... You can have besides extensive collections of Australian plants, if you will kindly let me have duplicates of yours when finally you come to distribute them.

After their meeting in Melbourne in 1878, their exchange of correspondence became more detailed with regard to botanical activities. In response to a letter written by Beccari soon after he departed Australia and which he had posted at Singapore, von Mueller (1878a) noted a number of botanical items:

[1 June 1878] It was very pleasing to me, dear Dr Beccari, to get your kind letter from Singapore, dated 19 April. Let me hope, that you will find your position in Florence amidst your riches \& treasures, congenial to your tastes! What a path of glory have you before you! As regards Signor D'Albertis's [Count Luigi Maria D'Albertis] plants, I shall of course be grateful for any, which you can spare me. I met D'Albertis here for two days, which was a source of great pleasure to me. He left a few living plants, which will likely come under my cognizance, when in flower. Australia is almost exhausted, so far as new plants are concerned. Hence I must rely on New Guinea or some other part of the globe for novelties. It is quite likely, that I mistook a Platea for a Lasianthera or Gomphandra, as I had not 
the benefit of using your excellent memoir on Olacineae, when I worked out the only Australian species as yet known. I will send you a specimen.

Disappointed with some aspects of their meeting in Melbourne, von Mueller (1878b) confided in William Thiselton-Dyer, Director of Kew Gardens, about this and wrote that:

I had a visit from Dr Beccari; what a humiliation of the "Princeps of Australian Botany" (as you considerately call me) to be obliged to tell the Director of the Botanic Garden of Florence, that his colleague here was a nurseryman, and that I could not set my foot into my own garden since 5 years with any self-respect.

Appointed Director of the Melbourne Botanic Gardens in 1857, von Mueller held the position until 1873 when he was controversially "relieved" of the directorship. His scientifically orientated garden designs and layouts were considered, both publicly and by government officials, not to have been providing appropriate "ornamental" character for such a prominent public facility and his official responsibilities were rewritten to exclude him from the botanic gardens management but to maintain him as Government Botanist (Cohn \& Maroske 1996).

Later, in a subsequent letter from von Mueller (1879) to Beccari, there was evidence of an increasing interest in the palm family:

[5 April 1879] Herewith, dear Dr Beccari, I send you the fruits of a new Areca from Trinity Bay [Areca alicae F.Muell.]. The species is allied to A. triandra \& A. oxycarpa. I have sent the description to Dr von Regels Garten-Flora. Let me thank you for the splendid 3rd fascicle of the Malesia! In what treasures you are revelling!! I quite envy you about your Rhododendrons orc.

Beccari's visit to Melbourne encouraged von Mueller to send an increasing number of palm specimens to Beccari who had seemingly been "assigned" by him as the primary taxonomic investigator of Australian palms. Subsequently, von Mueller (1887) wrote to Beccari stating that:

[10 March 1887] I have put a few specimens of Australian palms together for you, dear Dr Beccari, such as recently were obtained, but - as you will be aware - these noble plants occur but very scantily in this part of the world. There is a new one among them, collected on the Bloomfield River by Miss Ellie Bauer to whom I should like it dedicated [Livistona humilis var. sclerophylla Becc. = L. muelleri F.M. Bailey]. The young lady just lost her father through death, so this naming of a palm in honor of herself, will cheer her in the present sorrow. According to departmental entries here, you received some years ago of all palms of Australia, so far as they are contained in my museum, fragments of leaves flowers and fruit, wherever such could be spared; but the material in my museum is now very limited, after Drude, Wendland \& Kew were supplied. Lord Howe's Island is rarely visited, and it is not easy to obtain specimens from there. Wendland o Drude gave however a good account of the palms from that Island. I should be very glad, if you would early publish a description of Miss Ellie's palm, as so much competition has arisen, that such plant may easily fall into the hands of another Botanist.

The last known letter from von Mueller to Beccari was sent in 1890 accompanying a palm specimen from New Guinea, and in which von Mueller (1890) noted that:

[13 March 1890] By this mail, dear Dr Beccari, I have posted to you the only specimen of an only palm [Heterospathe macgregorii (Becc.) H.E. Moore], received from Sir William Macgregor among the dried plants, gathered by his Excellency on his tour up the Fly-River. Will you be so kind, to send a few fragments back for the Government Herbarium here, after you have examined the species. Three iron cylinders, filled with methylized alcohol, and sent for collecting purposes by me, will be this week emptied of the botanic specimens, contained therein. Should palms be among them they will be also sent to you.

From Beccari's Papuan collections, von Mueller named one species to honour Beccari (Myrtella beccarii F.Muell. (= Fenzlia beccarii (F.Muell.) Burret), collected from Humboldt Bay (Yos Sudarso Bay, Papua) (Mueller 1875-77). He was later to name a second species to honour Beccari, the palm Kentia beccarii F.Muell. (= Hydriastele montana (Becc.) W.J.Baker \& Loo) (Mueller 1880). Beccari was to return the eponymous favour, naming three new plant species to honour von Mueller: the epiphytic ant-plant Myrmecodia muelleri (F.Muell.) Becc., and two palms, Normanbya muelleri Becc. (=Normanbya normanbyi (W.Hill) L.H.Bailey) and Ptychandra muelleriana Becc. (=Heterospathe muelleriana (Becc.) Becc.).

\section{SUMMARY}

The visit of Beccari and D'Albertis to Australia and New Zealand has been somewhat overlooked by Australian and New Zealand scientists. Although their visit was primarily a leisure tour, they made some significant collections, in particular of bryophytes and ants. As their specimens were returned to institutions in Italy, there may have been some "cultural blockage" in such information becoming available to scientists in Australia and New Zealand. There was considerable collaboration between Beccari and Ferdinand von Mueller with regard to botanical research, but no other obvious collaboration with other Australian or New Zealand scientists has been identified. This paper has provided an overview of their travel itinerary and, as far as possible, has presented and annotated the various specimens that were collected by Beccari and D'Albertis in Australia and New Zealand.

\section{ACKNOWLEDGEMENTS}

For assistance with biographical information concerning Captain Enrico D'Albertis I thank Anna Giulia D'Albertis (Enrico's great grandniece) and for information about Castello D'Albertis I thank Maria Camilla de Palma. Library 
resources were provided by Paolo Salvi, University of Florence; Linda McGregor, Alexander Turnbull Library, Wellington, New Zealand; Alessandra Lenzi and Daniela Pozzi, Museo Galileo, Florence; and Philippa Robinson, Auckland Museum Library. For reviewing moss taxonomy, I thank Pina Milne, National Herbarium of Victoria. Information and images of herbarium and museum specimen were generously provided by Chiara Nepi, Florence; Nimal Karunajeewa, National Herbarium of Victoria; and Kathryn Medlock, Tasmanian Museum and Art Gallery. I thank Sara Maroske, Mueller Correspondence Project, Royal Botanic Gardens Melbourne, for providing copies of correspondence between Beccari and von Mueller. For assistance with translation of Italian to English, I thank Chiara Nepi who assisted with translation of Beccari's notebook.

\section{REFERENCES}

Aiuti, L. 1901: Elenco dei duplicati di piante secche offerte in cambio dal R. Istituto botanico di Firenze. Luigi Niccolai, Firenze: 4 pp.

Andreone, F. , Bartolozzi, L., Boano, G., Boero, F., Bologna, M.A., Bon, M., Bressi, N., Capula, M., Casale, A., Casiraghi, M., Chiozzi, G., Delfino, M., Doria, G., Durante, A., Ferrari, M., Gippoliti, S., Lanzinger, M., Latella, L., Maio, N., Marangoni, C., Mazzotti, S., Minelli, A., Muscio, G., Nicolosi, P., Pievani, T., Razzetti, E., Sabella, G., Valle, M., Vomero, V. \& Zilli, A. 2014: Italian natural history museums on the verge of collapse? ZooKeys 456: 139-146.

Anon. 1877: Notes. Nature: A Weekly Illustrated Journal of Science 17: $52-54$.

Anon. 1879: Report of the Royal Society of Tasmania for the Year 1878. James Barnard, Hobart Town.

Ballard, C. 2009: The art of encounter: verisimilitude in the imaginary exploration of the interior of New Guinea, 1725-1876. In Jolly, M., Tcherkézoff, S. \& Tryon, D.T. (eds): Oceanic Encounters; Exchange, Desire, Violence. ANU E Press, Canberra: 221-257.

Beccari, O. 1878a: Australia con D'Albertis, 1877-1878. Giornale delle spese 16. Biblioteca di scienze, Università degli Studi di Firenze. Unpublished manuscript.

Beccari, O. 1878b: Sulle piante raccolte alla Nuova Guinea dal. Sig. L.M. D'Albertis durante l'anno 1877, con descrizione di tre nouve specie di Icacineae. Malesia 1: 255-257.

Beccari, O. 1904: Wanderings in the Great Forests of Borneo: Travels and Researches of a Naturalist in Sarawak. Archibald Constable, London: 424 pp.

Beccari, O. 1924: Nova Guinea, Selebes e Molucche. Diari di Viaggio Ordinati dal Figlio Prof. Dott. Nello Beccari. La Voce, Florence: 468 pp.

Biagioli, B. 2005: L'Archivo Odoardo Beccari nella Biblioteca del Dipartimento di Biologia Vegetale Università degli Studi di Firenze, www.sba.unifi.it/upload/scienze/inventaripdf/ Archivo_Beccari.pdf (accessed November 2015).

Bitter, G. 1910: Die gattung Acaena. Vorstudium zu einer monographie. Bibliotheca Botanica 17(74): 1-336.

Burkill, I. H. \& Moulton, J.C. 1921: Odoardo Beccari. Journal of the Straits Branch of the Royal Asiatic Society 83: 166-173.

Capocaccia, L. \& Poggi, R. 1982: Short history of the Museo Civico di Storia Naturale "Giacomo Doria" in Genoa, Italy. Archives of Natural History 11(1): 107-122.

Chazdon, R.L. \& Earl of Cranbrook 2002: Tropical naturalists of the sixteenth through nineteenth centuries. In Chazdon, R.L. \& Whitmore, T.C. (eds): Foundations of Tropical Forest
Biology: Classic Papers with Commentaries. University of Chicago Press, Chicago: 5-14.

Clauser, M., Cecche, L., Grigioni, A. \& Lombardini, C. 2013: Lazione degle orti botanici per l'introduzione di piante utili o scientificamente importanti. Altre Modernità 10-11: 153-163.

Clouse, R. \& Giribet, G. 2012: On the Cyphothalmi (Arachnida, Opiliones) types from the Museo Civico di Storia Naturale "Giacomo Doria". Bulletin of the Museum of Comparative Zoology 160(5): 241-257.

Cognetti de Martiis, L. 1910: Nuove specie dei generi Megascolides e Pheretima. Annali del Museo Civico di Storia Naturale di Genova ser. 3(4) 44: 327-334.

Cohn, H.M. \& Maroske, S. 1996: Relief from duties of minor importance: the removal of Baron von Mueller from the directorship of the Melbourne Botanic Gardens. Victorian Historical Magazine 67(247): 103-127.

Cora, G. 1880: Explorazioni di Beccari nell'ovest di Sumatra (1878). Cosmos: Communicazioni sui Progressi piú Recenti e Notevoli della Geografia e delle Scienze Affini 5: 261-263.

Cuccuini, P. 2009: L'Erbario delle palme di Odoardo Beccari. In Raffaeli, M. (ed): Il Museo di Storia Naturale dell'Università degli Studi di Firenze, Vol. 2, Le Collezioni Botaniche, Firenze: Firenze University Press, Firenze: 133-152.

Cuccuini, P. \& Nepi, C. 2006: The palms of Odoardo Beccari. Quaderni di Botanica Ambientale e Applicata 17/1: 5-251.

D'Agnese, G. 2007: D'Albertis alla ricerca degli Hopi. Magazine Domenicale di America Oggi, 16 September 2007. www. oggi7.info (accessed November 2015).

D'Albertis, E.A. 1878: Ciarpe, frastagli e scampoli. Archivio Castello D'Albertis, Settore Musei e Biblioteche Comune di Genova. Unpublished manuscript.

D'Albertis, L.M. 1880: New Guinea: What I Did and What I Saw. 2 Volumes. S. Low Marston, Searle \& Rivington, London: 424 pp \& 406 pp.

De Palma, M.C. 2008: Castello d'Albertis: Museo delle Culture del Mondo. Silvana Editoriale, Milan: 80 pp.

De Pascale, A. 2008: Enrico Alberto D’Albertis: il finalese e la collaborazione con Arturo Issel. In De Pascale, A., Del Lucchese, A. \& Raggio, O. (eds): La Nascita della Paletnologia in Liguria: Personaggi, Scoperte e Collezioni tra XIX e XX Secolo, Atti del Convegno (Finale Ligure Borgo, 22-23 settembre 2006)). Bordighera, Ligure: 337-346.

De Pascale, A. 2009: Enrico Alberto D’Albertis (1846-1932) e la sua collezione archeologica. In Gandolfi, D. \& Venturino Gambari, M. (eds): Colligite Fragmenta: Aspetti e Tendenze del Collezionismo Archeologico Ottocentesco in Piemonte, Atti del Convegno (Tortona, 19-20 gennaio 2007). Bordighera, Ligure: $325-330$.

Doria, G. [Giacomo] 1878: Naturalisti Italiani alla Nuova Guinea. Bollettino della Società Geografica Italiana, 2nd ser. 3(15): 154-169.

Doria, G. [Giuliano] 2010: La collezione erpetological del Museo Civico di Storia Naturale "G. Doria" di Genova. Museologia Scientifica Memorie 5: 62-68.

Emery, C. 1886: Catalogo delle formiche esistenti nelle collezioni del Museo Civico di Genova. Parte terza. Formiche della regione Indo-Malese e dell'Australia. Annali del Museo Civico di Storia Naturale Giacomo Doria (Genova), 2nd ser. 4(24): 209-258.

Emery, C. 1887: Catalogo delle formiche esistenti nelle collezioni del Museo Civico di Genova. Parte terza. Formiche della regione Indo-Malese e dell'Australia (Continuazione e fine). Annali del Museo Civico di Storia Naturale Giacomo Doria (Genova), 2nd ser. 4(24): 427-473.

Fornaroli, L.A. 1935: Enrico Alberto d'Albertis, 1846-1932: E un'Appendice sul Castello di Montegalletto. Bozzo \& Coccarello, Genova: 317 pp.

Friend, J.A. 1987: The terrestrial amphipods (Amphipoda: Talitridae) of Tasmania: systematics and zoogeography. Records of the Australian Museum, Supplement 7: 1-85. 
Gandawijaja, D., Idris, S. \& Nasution, R. 1983: Amorphophallus titanum Becc.: a historical review and some recent observations. Annals of Botany 51(3): 269-278.

George, A.S. 2009: Australian Botanist's Companion. Four Gables Press, Kardinya, Western Australia: $671 \mathrm{pp}$

Gnecchi-Ruscone, E. 2011: From New Guinea 1872-78 to Genova 2004: recovering Luigi Maria D'Albertis' private collection. Journal de la Société des Océanistes 132: 165-182.

Graniti, A. 2004: Storia delle scienze sperimentali.- Due letter di Odoardo Beccari a Guiseppe de Notaris: le epatiche di Borneo e le vicende di due grandi Italiani. Rendiconti Fisiche e Accademia Lincei, 9th ser. 15: 159-168.

Hampe, E. \& Geheeb, A. 1881: Musci frondosi in Tasmania et Nova-Seelandia a Dr. O. Beccari, anno 1878, lecti. Revue Bryologique 8(2): 25-28.

Hooker, J.D. 1891: Amorphophallus titanum. Native of Sumatra. Curtis's Botanical Magazine 3rd series, 47(553) (1247): $7153-7155$

Isoviita, P. \& Ochyra, R. 1990: (975) Proposal to conserve Drepanocladus (Musci, Amblystegiaceae). Taxon 39(2): 348-351.

Jackson, B.D. 1922: Obituary notices. Proceedings of the Linnean Society of London 134: 37-40.

Lydon, J. 2014: Picturing Macassan-Australian histories: Odoardo Beccari's 1873 photographs of the "Orang-Mereghi" and indigenous authenticity. In Carey, J. \& Lydon, J. (eds): Indigenous Networks: Mobility, Connections and Exchange. Routledge, New York: 140-166.

Mattirolo, O. 1897: Enumerato seminum in $R$ Horto Botanico Florentiono anno MDCCCXCVII collectorum.

Moore, H.E. Jr. 1981: Odoardo Beccari (1843-1920). Principes 25: $29-35$.

Mueller, F. von. 1875-1877: Descriptive Notes on Papuan plants, Parts 1-5. Melbourne, George Skinner.

Mueller, F. von. 1877: Letter: Ferdinand von Mueller to Odoardo Beccari, 1877, 31 December. University of Florence, Science Library: Botany, Archives, Beccari 12/32.

Mueller, F. von. 1878a: Letter: Ferdinand von Mueller to Odoardo Beccari, 1878, 1 June. University of Florence, Science Library: Botany, Archives, Beccari 12/32.

Mueller, F. von. 1878b: Letter: Ferdinand von Mueller to William Thiselton-Dyer, 1878, 12 May, RBG Kew. Kew correspondence, Australia, Mueller, 1871-81, ff. 211-14.

Mueller, F. von. 1879: Letter: Ferdinand von Mueller to Odoardo Beccari, 1879, 5 April. University of Florence, Science Library: Botany, Archives, Beccari 12/32.
Mueller, F. von. 1880: Select Extra-tropical Plants Readily Eligible for Industrial Culture or Naturalisation, with Indications of their Native Countries and Some of their Uses. Office of the Superintendent of Government Printing, Calcutta: 394 pp.

Mueller, F. von. 1887: Letter: Ferdinand von Mueller to Odoardo Beccari, 1887, 10 March. University of Florence, Science Library: Botany, Archives, Beccari 12/32.

Mueller, F. von. 1890: Letter: Ferdinand von Mueller to Odoardo Beccari, 1890, 13 March. University of Florence, Science Library: Botany, Archives, Beccari 12/32.

Müller, C. 1897: Symbolae ad bryologiam Australiae I. Hedwigia 36: 331-365.

Nepi, C. 2009: L'Erbario delle Malesia di Odoardo Beccari. In Raffaeli, M. (ed): Il Museo di Storia Naturale dell'Università degli Studi di Firenze. Vol. 2, Le Collezioni Botaniche Firenze University Press, Firenze: 117-132.

Nizamuddin, M., West, J.A. \& Menez, E.G. 1978: A list of marine algae from Libya. Botanica Marina 22: 465-476.

Orlandi, L. 2009: A "Turkish salon" in the domestic collection of the Genoese gentleman and traveller Enrico A. D'Albertis (1846-1932). In Dávid, G. \& Gerelyes, I. (eds): Thirteenth International Congress of Turkish Art. Hungarian National Museum, Budapest: 519-531.

Pichi-Sermolli, R.E.G. \& van Steenis, C.G.G.J. 1983: Dedicated to the memory of Odoardo Beccari. Flora Malesiana, 1st ser. 9: 7-44.

Pollacci, G. 1935: Odoardo Beccari. Atti dell'1stituto Botanico dell'Università di Pavia, 4th ser. 6: 1-13.

Ramsay, H.P. 2006: History of research on Australian mosses. Flora of Australia 51: 1-19. Australian Biological Resources Study \& CSIRO Publishing, Melbourne.

Ruffo, S. 1949: Studi sui crostacei anfipodi XVII, gli anfipodi del Museo Civico di Storia Naturale di Genova, anfipodi di Sumatra, Celebes, Nuova Guinea, Australia e Tasmania. Annali del Museo Civico di Storia Naturale Giacomo Doria 63: 205-217.

Sayre, G. 1977: Authors names of bryophytes and the present location of their herbaria. The Bryologist 80: 502-521.

Surdich, F. 1985: D’Albertis, Enrico Alberto. Dizionario Biografico degli Italiani, Vol. 31, www.treccani.it/enciclopedia (accessed October 2015).

Taylor, R.J. \& McQuillan, P.B. 1994: Fauna of Mount Wellington. The Tasmanian Naturalist 116: 2-19.

Van Steenis, C.G.G.J. 1952: Thesaurus Beccarianus. Webbia 8: 427-436.

Van Steenis-Kruseman, M.J. 1950: Malaysian plant collectors and collections. Flora Malesiana 1(1): vii-clii, 3-639.

(Accepted 6 September 2016) 


\section{Appendix 1}

\section{AN ANNOTATED ITINERARY OF ODOARDO BECCARI AND ENRICO D'ALBERTIS IN AUSTRALIA/NEW ZEALAND, 1878}

The details of the itinerary were derived from three primary sources: A diary kept by Beccari (1878a); a scrap book of receipts, dockets, business-cards and newspaper clippings kept by D'Albertis (1878) and D’Albertis' travel notes as presented by Fornaroli (1935) which dealt with the entire 1877-1878 period. Additional details were sourced from newspapers of the time, mostly in items related to shipping, editorials and social notes.

\begin{tabular}{|c|c|}
\hline Dates & Locations and notes \\
\hline \multicolumn{2}{|l|}{1877} \\
\hline $24 \mathrm{Oct}$ & Odoardo Beccari and Enrico D’Albertis depart Genoa, Italy, on the M.S. Australia. \\
\hline $1-3 \mathrm{Nov}$ & Suez Canal, Port Said. \\
\hline $9 \mathrm{Nov}$ & Aden. \\
\hline 16 Nov-12 Dec & Overland across India from Bombay [Mumbai] to Calcutta [Kolkata]. \\
\hline \multicolumn{2}{|l|}{1878} \\
\hline 3 Dec - 7 Jan & Departed Calcutta on the S.S. Mecca to Burma [Myanmar], Penang, Malacca, Singapore and Sarawak. \\
\hline 7-10 Jan & Singapore. \\
\hline 11 Jan & Departed Singapore on the S.S. Brisbane. \\
\hline 19 Jan & Thursday Island. \\
\hline 20-21 Jan & Somerset. \\
\hline 23 Jan & Cooktown. \\
\hline $24 \mathrm{Jan}$ & Townsville, Bowen. (The Queenslander. "Correspondent. Via Torres Straits". 26 January 1878, p. 21) \\
\hline 25 Jan & $\begin{array}{l}\text { Percy Islands. D'Albertis (1878) reported in a letter to Giacomo Doria: "We passed Bowen, then Percy Island in the } \\
\text { Northumberland group where we made some collections, and finally to Keppel Bay". The collections consisted of botanical } \\
\text { and zoological specimens. The plant specimens were later deposited in Ferdinand von Mueller's Phytologic Museum } \\
\text { of Melbourne, now the National Herbarium of Victoria, and the ant specimens were returned to the Museo Civico } \\
\text { di Storia Naturale in Genoa. }\end{array}$ \\
\hline $26 \mathrm{Jan}$ & Keppel Bay, Curtis Island. \\
\hline 27 Jan & $\begin{array}{l}\text { Moreton Bay, Brisbane: visited the Botanic Garden and the observatory. (The Brisbane Courier. 'Shipping'. } 28 \\
\text { January } 1878, \text { p. 2) }\end{array}$ \\
\hline 28 Jan & Departed Brisbane. \\
\hline $30 \mathrm{Jan}-2 \mathrm{Feb}$ & $\begin{array}{l}\text { Sydney [Royal Hotel]; granted honorary membership of the Australian Club (The Australian Town and Country } \\
\text { Journal. 'Shipping'. } 2 \text { February1878, p. 36) }\end{array}$ \\
\hline 2 Feb & Departed Sydney by train to Bowning. \\
\hline 3 Feb & $\begin{array}{l}\text { Departed Bowning by coach to Jugiong, Gundagai to Albury and then by train to Melbourne; at least two ant } \\
\text { specimens were collected during the "overland" travel between Sydney and Melbourne. }\end{array}$ \\
\hline 4-11 Feb & Melbourne [Union Club Hotel, Collins Street West]. (The Argus. 'Editorial'. 6 February 1878, p. 5). \\
\hline $6 \mathrm{Feb}$ & $\begin{array}{l}\text { Melbourne; visited the Botanic Gardens with Ferdinand von Mueller, the Melbourne Observatory and met Robert } \\
\text { Lewis John Ellery, Government Astronomer and President of the Royal Society of Victoria. }\end{array}$ \\
\hline 7 Feb & Visited Ballarat to examine the gold mines. \\
\hline $7 \mathrm{Feb}$ & $\begin{array}{l}\text { Melbourne; met with Sir Redmond Barry, Victorian Colonial Judge and Chancellor of the University of Melbourne, } \\
\text { visited the Library, Museum, Hospital, Melbourne Club, Parliament House, Government Offices, Athenaeum Club } \\
\text { and Zoological Gardens where they saw echidnas, the now extinct thylacine (Tasmanian tiger), dingoes and kangaroos. }\end{array}$ \\
\hline $8 \mathrm{Feb}$ & $\begin{array}{l}\text { Melbourne; visited the University and Museum, met Sir Frederick McCoy, Director of the Victorian Museum and } \\
\text { Professor of Natural Sciences at Melbourne University. }\end{array}$ \\
\hline 9 Feb & $\begin{array}{l}\text { Melbourne; lunched with John Pigdon, Mayor of Melbourne, met with the photographer John William Lindt who } \\
\text { took a carte-de-visite of both Beccari and D'Albertis (see pls 1,2) and in the evening dined at Government House } \\
\text { with Governor George Ferguson Bowen and Lady Bowen, Contessa Diamantina di Roma. }\end{array}$ \\
\hline $12 \mathrm{Feb}$ & Departed Melbourne for Tasmania on the S.S. Derwent. \\
\hline $13 \mathrm{Feb}$ & $\begin{array}{l}\text { Tamar Heads, Corra Linn, Deloraine, Launceston [Criterion Hotel]. (The Mercury. 'By electric telegraph. Tamar } \\
\text { Heads'. } 14 \text { February 1878, p. 2); Collected plant and ant specimens. }\end{array}$ \\
\hline $16 \mathrm{Feb}$ & Departed Launceston by train to Hobart. \\
\hline 16-23 Feb & Hobart [Ship Hotel]. \\
\hline $19 \mathrm{Feb}$ & $\begin{array}{l}\text { Mount Wellington; collected bryophytes, vascular plants, crustaceans and earthworms at Huon Road and Mount } \\
\text { Wellington (Taylor \& McQuillan 1994). On Mount Wellington, D'Albertis measured a giant Eucalyptus to } 76 \mathrm{~m} \\
\text { tall with a circumference of } 13.2 \mathrm{~m} \text {. }\end{array}$ \\
\hline
\end{tabular}


Appendix 1 cont.

$20 \mathrm{Feb} \quad$ Hobart, New Norfolk; visited the museum and gardens, and the salmon hatchery. At this time, "eight prepared skins of New Guinea birds" collected by Beccari were received by the Royal Society of Tasmania (Anon. 1879). It is possible that Beccari delivered them personally, however no record survives of the mode of delivery (Kathryn Medlock pers. comm.).

23 Feb Departed Hobart for New Zealand on the S.S. Tararua.

26-27 Feb Bluff Harbour, Invercargill. (The Southland Times. 'Bluff Harbour'. 28 February 1878, p. 2). A bryophyte specimen was collected at Bluff.

$28 \mathrm{Feb} \quad$ By railway to Clinton.

29 Feb-2 Mar By coach to Balclutha, Dunedin.

2 Mar Dunedin, Moeraki, Blueskin Bay via Port Chalmers. D’Albertis recorded that they collected seeds of Cordyline australis [as Dracoena], "Ombrellaria” [possibly Schefflera digitata] and Rhopalostylis sapida [Nikau palm].

3 Mar By train to Mount Omaru, via Timaru to Christchurch.

$4 \mathrm{Mar} \quad$ Christchurch; Canterbury Museum, met with Julius von Haast.

5 Mar Departed Lyttelton on the S.S. Taupo. (The Star. 'Sailed'. 6 March 1878, p. 2).

6 Mar Wellington (The Evening Post. 'Shipping'. 6 March 1878, p. 2).

7 Mar Departed Wellington by train for Napier and reboarded the S.S. Taupo at Hawke's Bay. They collected an ant specimen from Napier.

8 Mar Hawke’s Bay [Napier] (The Hawke’s Bay Herald. "Arrivals". 9 March 1878, p. 2).

9 Mar Poverty Bay [Gisborne], Tauranga.

10-12 Mar Auckland [Northern Club] (The New Zealand Herald. "Shipping”. 11 March 1878, p. 2).

$11 \mathrm{Mar} \quad$ Auckland; visited the Auckland Museum and Institute and met Justice Thomas Gillies and geologist James Hector (The New Zealand Herald. [Editorial]. 12 March, 1878, p. 2). Later the same day they were taken to the Waitakerei Ranges and Titirangi by the botanist Thomas Cheeseman. (The New Zealand Herald. [Editorial]. 13 March, 1878, p. 2). Specimens were collected by Beccari at Titirangi, including bryophytes, ants, an earthworm and a specimen of the nikau palm Rhopalostylis sapida (Cuccuini \& Nepi 2006).

$12 \mathrm{Mar} \quad$ Departed Auckland for Australia on the R.M.S. Australia (The Auckland Star. "Departure of the Australia". 13 March 1878, p. 2).

17-23 Mar Arrived in Sydney [Royal Hotel] (The Evening News. “Shipping”. 18 March 1878, p. 2).

18-19 Mar Travelled by train to the Blue Mountains; D’Albertis noted that they collected specimens of plants, "blues” [butterflies?] and ants. However, only specimens of the latter have been located.

$23 \mathrm{Mar} \quad$ Departed Sydney on the R.M.S. Bowen.

$25 \mathrm{Mar} \quad$ Brisbane (The Morning Bulletin. "Shipping Movements". 1 April 1878, p. 2).

$26 \mathrm{Mar} \quad$ Overnight train to Toowoomba.

27 Mar Brisbane [Metropolitan Hotel].

$28 \mathrm{Mar} \quad$ Beccari visited the Brisbane Botanic Gardens and collected specimens of the palms Archontophoenix alexandrae and Syagrus romanzoffiana (Cuccuini \& Nepi 2006). Beccari made a brief diary note about the palm collection: "Caryota alberti [I] saw a specimen with trunk 30 feet high [in the] Botanical Gardens of Brisbane. Surely it doesn't seem to look like C. rumphii. Saguerus of C. York, is different to S. saccharifer because it is stoloniferous. In Brisbane [there are] various species of Cocos, Caryota, Arenga, Licuala. They survive very well outdoors" (Beccari 1878a). Beccari was to later clarify his identification of the Caryota species that he saw in Brisbane Botanic Gardens, noting that it: "seems very likely that the Caryota alberti F. von Mueller from Cape York is identical to the Caryota from the Fly River. Indeed I saw a fine specimen of the species from Cape York living in the Brisbane Botanic Gardens, and based on the size and shape of the trunk it was similar to Caryota rumphiana" (Beccari 1878b).

$28 \mathrm{Mar} \quad$ Departed Brisbane on the R.M.S. Bowen.

$29 \mathrm{Mar} \quad$ Keppel Bay (The Brisbane Courier. 'Shipping'.1 April 1878, p. 2).

$30 \mathrm{Mar} \quad$ Bowen.

$31 \mathrm{Mar} \quad$ Townsville.

1 Apr Cooktown.

5 Apr Thursday Island (The Brisbane Courier. "Shipping”. 3 April 1878, p. 2).

$15 \mathrm{Apr} \quad$ Singapore (The Straits Times. “Overland Journal”. 18 April 1878, p. 1).

14 Oct D’Albertis arrived at Genoa.

$28 \mathrm{Dec} \quad$ Beccari arrived at Florence. 


\title{
Appendix 2
}

\section{VASCULAR PLANTS, BRYOPHYTES, CRUSTACEANS, ANTS AND EARTHWORMS COLLECTED BY ODOARDO BECCARI AND ENRICO D'ALBERTIS IN AUSTRALIA AND NEW ZEALAND, 1878}

\begin{abstract}
New species based on a Beccari/D'Albertis specimen are preceded by an *. The original name appears first, and the current name follows in brackets. Collection date is known or determined from the travel itinerary. Location of specimens is given where known. Taxonomy and nomenclature of Australian vascular plants follows the Australian Plant Name Index and for New Zealand vascular plants the Flora of New Zealand; Bryophyte taxonomy follows AusMoss; Ant taxonomy follows the Atlas of Living Australia and Ant Web; and Earthworms follow the ITIS Report.

Herbarium and museum acronyms. B: Botanischer Garten und Botanisches Museum Berlin-Dahlem, Germany; BM: Natural History Museum, London; FI: Museo di Storia Naturale dell'Università di Firenze, Italy; H-BR: University of Helsinki, Finland; L: Nationaal Herbarium Nederland, The Netherlands; MEL: National Herbarium of Victoria, Royal Botanic Gardens Melbourne, Australia; MSNG: Museo Civico di Storia Naturale di Genova, Italy; TENN: University of Tennessee, USA; NSW: National Herbarium of New South Wales, Royal Botanic Gardens Sydney, Australia; NY: The New York Botanical Garden, The Bronx, USA.
\end{abstract}

\begin{tabular}{lc}
\hline Original name, current name and specimen; location of specimen & Citation or publication reference
\end{tabular}

\section{VASCULAR PLANTS}

*Acaena sanguisorbae var. brevifoliolata Bitter; Australia, Tasmania, Mt Wellington, 19 Feb. Biblioth. Bot. 17(74): 263 (1911).

1878, Beccari s.n.; FI

*Acaena sanguisorbae var. subincisa Bitter; Australia, Tasmania, Mt Wellington, 19 Feb. 1878, Beccari s.n.; FI

Allocasuarina littoralis (Salisb.) L.A.S.Johnson, Australia, Qld. Percy Islands, 1878, Beccari n/a s.n.; MEL 0545833.

Archontophoenix alexandrae (F.Muell.) H.Wendl. \& Drude Australia, Brisbane Botanic

Garden, 28 Mar. 1878, O. Beccari s.n.; FI.

Coronidium cymosum Paul G.Wilson, Australia, Qld. Percy Islands, 1878, Beccari s.n.; MEL 2115498.

Helichrysum elatum A.Cunn. ex DC.[Coronidium elatum (A.Cunn. ex DC.) Paul G.

Wilson], Australia, Qld. Percy Islands, 1878, Beccari s.n.; MEL 2160996.

Grewia retusifolia Kurz, Australia, Qld. Percy Islands, 1878, Beccari s.n.; MEL 1599215.

Leucopogon leptospermoides R.Br., Australia, Qld. Percy Islands, 1878, Beccari s.n.; MEL 0088992 .

Pityrodia salviifolia R.Br., Australia, Qld. Percy Islands, 26 Jan, 1878, Beccari s.n.; FI.

Portulaca sp., Australia, Qld. Percy Islands, 1878, Beccari s.n.; MEL 0025735.

Rhopalostylis sapida (Sol. ex G.Forst.) H.Wendl. \& Drude; New Zealand, North Island, Titirangi Range near Auckland, 12 Mar. 1878, Beccari s.n.; FI.

Senecio quadridentatus Labill.; Australia, Tasmania, 'Corra Leen' [Corra Linn], 13 Feb. 1878, Beccari s.n.; FI.

Cocos romanzoffiana Cham. [Syagrus romanzoffiana (Cham.) Glassman]: Australia, Brisbane Botanic Garden, Beccari s.n.; FI.

Biblioth. Bot. 17(74): 263 (1911).

Quad. Bot. Amb. Appl. 17: 149 (2006).

$\mathrm{n} / \mathrm{a}$

$\mathrm{n} / \mathrm{a}$

$\mathrm{n} / \mathrm{a}$

$\mathrm{n} / \mathrm{a}$

J. Adelaide Bot. Gard. 2: 10 (1979).

$\mathrm{n} / \mathrm{a}$

Quad. Bot. Amb. Appl. 17: 150 (2006).

Ann. Missouri Bot. Gard. 43: 58. (1956).

Quad. Bot. Amb. Appl. 17: 66 (2006).

\section{BRYOPHYTES}

*Bryum beccarii Müll.Hal. [Pohlia nutans (Hedw.) Lindb.]; Australia, Tasmania, Mt Wellington, 19 Feb. 1878, Beccari s.n. [Named for Odoardo Beccari, collector of the type specimen].

*Dicranum brunneum Müll.Hal., Australia, Tasmania, Mt Wellington, 19 Feb. 1878, Beccari s.n.

*Dicranum campyperoideum Müll.Hal., New Zealand, Titirangi, 11 Mar.1878, Beccari s.n.; [Herb. Geheeb] BM.

*Dicranum kroneanum Müll.Hal., Australia, Tasmania, Mt Wellington, 19 Feb. 1878, Beccari 13; holotype B, destroyed; lectotype: L. [Named for Hermann Krone (18271916), German photographer and bryophyte collector who visited Australia and New Zealand in 1874-75].

*Dissodon longicollis Müll.Hal. [Tayloria octoblepharis (Hook.) Mitt.], New Zealand, North Gen. musc. Frond. 124 (1901). Island, Beccari s.n.; B? destroyed?

Hedwigia 37: 87 (1898).

Hedwigia 36: 352 (1897).

Hedwigia 36: (1897).

Rev. Bryol. 8: 26 (1881). 
Appendix 2 cont.

*Fissidens tortuosus Geh. \& Hampe [Fissidens rigidulus Hook.f. \& Wilson var. rigidulus]; Australia, Tasmania, Mt Wellington, 19 Feb. 1878, Beccari 25.

*Leptotheca beccarii Müll.Hal. [Leptotheca gaudichaudii Schwägr. var. gaudichaudii], Australia, Tasmania, Mt Wellington, 19 Feb. 1878, Beccari 22; lectotype: FI; isolectotype: NY00913954. [Named for Odoardo Beccari, collector of the type specimen]

*Mniadelphus beccarii Müll.Hal. [Distichophyllum rotundifolium (Hook.f. \& Wilson) Müll.Hal. \& Broth.], Australia, Tasmania, Mt Wellington, 19 Feb. 1878, Beccari s.n. [Named for Odoardo Beccari, collector of the type specimen]

*Polytrichum beccarii Müll.Hal. [Polytrichum juniperinum Hedw.]; Australia, Tasmania, Mt Wellington, 19 Feb, 1878, Beccari s.n.: isotype: H-Br. [Named for Odoardo Beccari, collector of the type specimen]

*Pterygophyllum levieri Geh. [Distichophyllum microcarpum (Hedw.) Mitt.], Australia, Tasmania, Mt Wellington, 19 Feb. 1878, Beccari 41. [Named for Emilio Levier (18391911), Swiss-born physician and bryologist, resident of Florence]

*Raphidostegium calliferum Geh. \& Hampe [Rhaphidorrhynchium amoenum (Hedw.) M.Fleisch. var. amoenum]; Australia, Tasmania, Mt Wellington, 19 Feb. 1878, Beccari 31. Andreaea acuminata Mitt., 19 Feb. 1878, Australia, Tasmania, Mt Wellington.

Bartramia mossmanniana Müll.Hal., Australia, Tasmania, Huon Rd., Mt Wellington, 19 Feb. 1878, Beccari 9.

Blindia robusta Hampe, Australia, Tasmania, Mt Wellington, 19 Feb. 1878, Beccari 12; TENN-B-0005029.

Breutelia comosa Mitt. [Breutelia pendula (Sm.) Mitt.]; Australia, Tasmania, Mt Wellington, 19 Feb. 1878, Beccari 26; TENN-B-0007650.

Campylopus capillatus Hook.f. \& Wilson [Campylopus pyriformis (Schultz) Brid.], New Zealand, Titirangi near Auckland, 11 Mar. 1878, Beccari 34.

Campylopus insititius Hook.f. [Campylopus clavatus Wilson], Australia, Tasmania, Mt. Wellington, 19 Feb. 1878, Beccari 15.

Campylopus introflexus (Hedw.) Brid., New Zealand, Titirangi near Auckland, 11 Mar. 1878, Beccari 39].

Campylopus torquatus Mitt. [Campylopus pyriformis (Schultz) Brid.], Australia, Tasmania, Huon Road, Mt Wellington, 19 Feb. 1878, Beccari 14.

Ceratodon crassinervis Lorentz [Ceratodon purpureus (Hedw) Brid.], Australia, Tasmania, Mt Wellington, 19 Feb. 1878, Beccari 2.

Coelidium chlamydophyllum (Hook.f. \& Wilson) A.Jaeger [Acrocladium chlamydophyllum (Hook.f. \& Wilson) Müll.Hal. \& Broth.], Australia, Tasmania, 19 Feb. 1878, Beccari 29.

Conostomum australe Sw. [Conostomum pentastichum (Brid.) Lindb.], Australia, Tasmania, Mt Wellington, 19 Feb. 1878, Beccari 8.

Cyathophorum bulbosum Müll.Hal., Australia, Tasmania, Mt Wellington, 19 Feb. 1878, Beccari 33.

Cyrtopus setosus (Hedw.) Hook.f., New Zealand, Titirangi near Auckland, 11 Mar. 1878, Beccari 31.

Dissodon cuspidatus Müll.Hal. [Tayloria octoblepharum (Hook.) Mitt.], New Zealand, Bluff, 26 Feb. [as Mar.] 1878, Beccari 38.

Distichium capillaceum (Hedw.) Bruch \& W.P. Schimper, Australia, Tasmania, Mt Wellington, 19 Feb. 1878, Beccari 3.

Gottschea lehmanniana (Lehm. \& Lindenb.) Nees] [Schistochila lehmanniana (Lehm. \& Lindenb.) Carrington \& Pearson]; Australia, Tasmania, Mt Wellington, Beccari s.n.

Hypnum chrysogaster Müll.Hal., Australia, Tasmania, Mt Wellington, 19 Feb. 1878, Beccari 28; NSW 760254

Hypnum crinitum Hook. \& Wilson [Wijkia extenuata (Brid.) H.A.Crum], Australia, Tasmania, Mt Wellington, 19 Feb. 1878, Beccari 30.

Leptostomum flexipile Müll.Hal. [Leptostomum inclinans R.Br.], Australia, Tasmania, Mt Wellington, 19 Feb. 1878, Beccari 5.

Leptotheca gaudichaudi Schwägr., Australia, Tasmania, Mt Wellington, 19 Feb. 1878, Beccari 22 \& 23.
Rev. Bryol. 8: 27 (1881).

Gen. musc. Frond. 148 (1901).

Rev. Bryol. 8: 26 (1881).

Hedwigia 36: 345 (1897).

Rev. Bryol. 8: 27 (1881).

Rev. Bryol. 8: 27 (1881).

Rev. Bryol. 8: 25 (1881).

Rev. Bryol. 8: 26 (1881).

Rev. Bryol. 8: 25 (1881).

Rev. Bryol. 8: 26 (1881).

Rev. Bryol. 8: 26 (1881).

Rev. Bryol. 8: 26 (1881).

Rev. Bryol. 8: 26 (1881).

Rev. Bryol. 8: 26 (1881).

Rev. Bryol. 8: 25 (1881).

Rev. Bryol. 8: 27 (1881).

Rev. Bryol. 8: 26 (1881).

Rev. Bryol. 8: 28 (1881).

Rev. Bryol. 8: 25 (1881).

Rev. Bryol. 8: 25 (1881).

Rev. Bryol. 8: 25 (1881).

Fragm. (Suppl.) 11: 61 (1880).

Rev. Bryol. 8: 27 (1881).

Rev. Bryol. 8: 27 (1881).

Rev. Bryol. 8: 26 (1881).

Rev. Bryol. 8: 26 (1881). 
Appendix 2 cont.

Leptotrichum oldfieldii Mitt. [Ditrichum difficile (Duby) M.Fleisch], Australia, Tasmania, Huon Road, Mt Wellington, 19 Feb. 1878, Beccari 1.

Mniadelphus pulchellus Hampe [Distichophyllum pulchellum (Hampe) Mitt.], Australia, Tasmania, Mt Wellington, Australia, 19 Feb. 1878, Beccari 24.

Mniodendron comatum (Müll.Hal.) Lindb., New Zealand, Titirangi near Auckland, 11 Mar. 1878, Beccari 36.

Philonotis fertilis Mitt. [Philonotis tenuis (Taylor) Reichardt], Australia, Tasmania, Mt Wellington, 19 Feb. 1878, Beccari 7.

Pogonatum australasicum (Müll.Hal. \& Hampe) A.Jaeger [Pogonatum neesii (Müll.Hal.) Dozy], Australia, Tasmania, Huon Road, Mt Wellington, 19 Feb. 1878, Beccari 16.

Polytrichadelphus arnoldii (Hampe) A.Jaeger [Polytrichadelphus magellanicus (Hedw.) Mitt.], Australia, Tasmania, Mt Wellington, 19 Feb. 1878, Beccari 17.

Polytrichum sullivani Hampe [Polytrichum juniperinum Hedw.], Australia, Tasmania, Mt Wellington, 19 Feb. 1878, Beccari 16.

Psilopilum australe (Hook.f. \& Wilson) Mitt. [Notoligotrichum australe (Hook.f. \& Wilson) G.L.Sm.], Australia, Tasmania, Mt Wellington, 19 Feb. 1878, Beccari 18.

Ptychomnium aciculare (Brid.) Mitt., Australia, Tasmania, Mt Wellington, 19 Feb. 1878 , Beccari 27; New Zealand, Titirangi near Auckland, 11 Mar. 1878, Beccari 35.

Rhizogonium novae-hollandiae (Brid.) Brid., Australia, Tasmania, undated, Beccari 20 \& 21.

Rhizogonium paramattense (Müll.Hal.) Reichardt [Pyrrobryum paramattense (Müll.Hal.) Manuel], Australia, Tasmania, Mt Wellington, 19 Feb. 1878, Beccari 6.

Sphagnum australe Mitt., Australia, Tasmania, Mt Wellington, 19 Feb. 1878, Beccari 32.

Trichostomum elongatum Hook.f. \& Wilson [Ditrichum cylindricarpum (Müll.Hal.)

F.Muell.], Australia, Tasmania, Mt Wellington, 19 Feb. 1878, Beccari 10.

Trichostomum laxifolium Hook.f. \& Wilson [Ditrichum difficile (Duby) M.Fleisch], Australia, Tasmania, Mt Wellington, 19 Feb, 1878, Beccari 1.

Webera nutans Hedw. [Pohlia nutans (Hedw.) Lindb.], Australia, Tasmania, Mt Wellington, 19 Feb. 1878, Beccari 4.

\section{CRUSTACEANS}

${ }^{*}$ Keratroides vulgaris (Friend, 1979), Australia, Tasmania, Mt Wellington, 19 Feb. 1878, Beccari \& E.D’Albertis s.n.; MSNG.

*Mysticotalitrus tasmaniae (Ruffo, 1949) [Talitrus tasmaniae (Ruffo, 1949)], Australia, Tasmania, Mt Wellington, 19 Feb. 1878, Beccari \& E.D'Albertis s.n.; syntype: MSNG. Talitrus sylvaticus (Haswell, 1879), Australia, Tasmania, Mt Wellington, 19 Feb. 1878, Beccari \& E.D'Albertis s.n.; MSNG.

\section{ANTS}

${ }^{*}$ Camponotus dorycus confusus (Emery, 1887), Australia, Percy Island, Beccari \& E.D'Albertis s.n.; MSNG.

*Camponotus nigriceps pallidiceps (Emery, 1887) [Camponotus pallidiceps (Emery, 1887)], Australia, Blue Mts, Beccari \& Enrico D’Albertis s.n.; syntype: MSNG.

*Dolichoderus doriae (Emery, 1887), Australia, Blue Mts, Beccari \& Enrico D’Albertis s.n.; MSNG.

Amblyopone australis (Erichson, 1842), Australia, Tasmania, Launceston, Beccari \& E.D'Albertis s.n.; MSNG.

Amblyopone cephalotes (Smith, 1876) [Amblyopone australis (Erichson, 1842)], New Zealand, Napier, Beccari \& E. D'Albertis s.n.; MSNG.

Camponotus ephippium (Smith, 1858), Australia, New South Wales, Overland, Beccari \& Enrico D'Albertis s.n.; MSNG.

Camponotus intrepidus (Kirby, 1818), Australia, Blue Mts, Beccari \& Enrico D’Albertis s.n.; MSNG
Rev. Bryol. 8: 25 (1881).

Rev. Bryol. 8: 26 (1881).

Rev. Bryol. 8: 27 (1881).

Rev. Bryol. 8: 26 (1881).

Rev. Bryol. 8: 26 (1881).

Rev. Bryol. 8: 26 (1881).

Rev. Bryol. 8: 26 (1881).

Rev. Bryol. 8: 26 (1881).

Rev. Bryol. 8: 27 (1881).

Rev. Bryol. 8: 26 (1881).

Rev. Bryol. 8: 26 (1881).

Rev. Bryol. 8: 25 (1881).

Rev. Bryol. 8: 25 (1881).

Rev. Bryol. 8: 25 (1881).

Rev. Bryol. 8: 26 (1881).

Pap. \& Proc. Roy. Soc. Tasmania 113: 85 (1979).

Ann. Mus. Civico Storia Nat. Giacomo Doria 63: 207 (1949).

Ann. Mus. Civico Storia Nat. Giacomo Doria 63: 206 (1949).

Ann. Mus. Civico Storia Nat. Genova, ser. 2(4), 24: 215 (1887).

Ann. Mus. Civico Storia Nat. Genova, ser. 2(4), 24: 211 (1887).

Ann. Mus. Civico Storia Nat. Genova, ser. 2(4), 24: 252 (1887).

Ann. Mus. Civico Storia Nat. Genova, ser. 2(5). 25: 446 (1887).

Ann. Mus. Civico Storia Nat. Genova, ser. 2(5), 25: 446 (1887).

Ann. Mus. Civico Storia Nat. Genova, ser. 2(4), 24: 211 (1887).

Ann. Mus. Civico Storia Nat. Genova, ser. 2(4), 24: 210 (1887). 
Appendix 2 cont.

Camponotus nigreceps dimidiatus (Roger, 1863) [Camponotus consobrinus (Erichson, 1842)], Australia, Blue Mts; Tasmania, Launceston, Beccari \& E.D’Albertis s.n.; MSNG.

Ectatomma metallicum (Smith, 1858) [Rhytidoponera metallica (Smith, 1858)], Australia, Tasmania, Launceston, Beccari \& E.D’Albertis s.n.; MSNG.

Iridomyrmex itinerans (Lowne, 1865) [Anonychomyrma itinerans (Lowne, 1865)], Australia, Blue Mts, Beccari \& Enrico D’Albertis s.n.; MSNG.

Iridomyrmex purpureus (Smith, 1858), Australia, Overland, Beccari \& Enrico D'Albertis s.n.; MSNG.

Iridomyrmex rufoniger (Lowne, 1865), Australia, Percy Island, Overland, Beccari \& E.D'Albertis s.n.; MSNG.

Leptomyrmex erythrocephalus (Fabricius, 1775), Australia, Blue Mts, Beccari \& Enrico D'Albertis s.n.; MSNG.

Leptomyrmex erythrocephalus nigriventris (Guérin, 1831), Australia, Blue Mts, Beccari \& Enrico D'Albertis s.n.; MSNG.

Monomorium antarcticum (Smith, 1858), New Zealand, Titirangi, Beccari \& E. D'Albertis s.n. MSNG.

Myrmecia auriventris (Mayr, 1870), Australia, Percy Island, Beccari \& E.D’Albertis s.n.; MSNG.

Myrmecia forficata (Fabricius, 1787), Australia, Tasmania, Launceston, Deloraine, Beccari \& E.D’Albertis s.n.; MSNG.

Myrmecia pilosula (Smith, 1858), Australia, Blue Mts, Tasmania, Launceston, Beccari \& Enrico D'Albertis s.n.; MSNG.

Myrmecia pyriformis (Smith, 1858), Australia, Blue Mts, Beccari \& E. D’Albertis s.n.; MSNG.

Polyrhachis femorata (Smith, 1858), Australia, Blue Mts, Beccari \& Enrico D’Albertis s.n.; MSNG.

\section{EARTHWORMS}

*Megascolides albertisii (Cognetti de Martiis, 1910) [Aporodrilus albertisii (Cognetti de Martiis, 1910)], Australia, Tasmania, Mt Wellington, 19 Feb., 1878, E.D'Albertis \& Beccari s.n.; MSNG [Named for Enrico D'Albertis, collector of the type specimen].

*Megascolides neglectus (Cognetti de Martiis, 1910), New Zealand, Titirangi near Auckland, 11 March 1878, E. D'Albertis \& Beccari s.n.; MSNG.
Ann. Mus. Civico Storia Nat. Genova, ser. 2(4), 24: 211 (1887)

Ann. Mus. Civico Storia Nat. Genova, ser. 2(4), 25: 444 (1887)

Ann. Mus. Civico Storia Nat. Genova, ser. 2(4), 24: 249 (1887)

Ann. Mus. Civico Storia Nat. Genova, ser. 2(4), 24: 249 (1887).

Ann. Mus. Civico Storia Nat. Genova, ser. 2(4), 24: 251 (1887).

Ann. Mus. Civico Storia Nat. Genova, ser. 2(4), 24: 252 (1887).

Ann. Mus. Civico Storia Nat. Genova, ser. 2(4), 24: 252 (1887).

Ann. Mus. Civico Storia Nat. Genova, ser. 2(5), 25: 458 (1887).

Ann. Mus. Civico Storia Nat. Genova, ser. 2(5). 25: 444 (1887).

Ann. Mus. Civico Storia Nat. Genova, ser. 2(5), 25: 443(1887).

Ann. Mus. Civico Storia Nat. Genova, ser. 2(5), 25: 444 (1887).

Ann. Mus. Civico Storia Nat. Genova, ser. 2(5), 25: 443 (1887).

Ann. Mus. Civico Storia Nat. Genova, ser. 2(4), 24: 225 (1887)

Ann. Mus. Civico Storia Nat. Genova, ser. 3(4), 44: 329 (1910)

Ann. Mus. Civico Storia Nat. Genova, ser. 3(4), 44: 327 (1910) 
